http://jmscr.igmpublication.org/home/ ISSN (e)-2347-176x ISSN (p) 2455-0450 crossref DOI: https://dx.doi.org/10.18535/jmscr/v9i8.09

\title{
Effect of Vitamin B12 on Renal function of albino rats infected with Trypanosoma brucei
}

\author{
Authors \\ Adebayo Olugbenga Adegoke ${ }^{1 *}$, Ibitoroko Maureen George-Opuda ${ }^{2}$, \\ Nnamdi Isaac Nnatuanya ${ }^{1}$, Marygolden Chika Umeh ${ }^{1}$ \\ ${ }^{1}$ Department of Medical Laboratory Science, Madonna University, Elele, Nigeria \\ ${ }^{2}$ Department of Medical Laboratory Science, Rivers State University, Port Harcourt, Nigeria \\ *Corresponding Author
}

Dr Adebayo O.Adegoke

Department of Medical Laboratory Science, Madonna University, Elele, Nigeria

\begin{abstract}
This study was carried out to determine the effect of vitamin B12 on the renal functions of male Wister albino rats infected with Trypanosoma brucei brucei. 24 male Wistar albino rats were divided into 6 groups of for rats each namely; control, Trypanosome infected, diamenazene treated, 40mcg vitaminB12, $60 \mathrm{mcg}$ vitamin B12,80mcg vitamin B12. The renal indicators such as urea, creatinine, sodium, potassium and chloride were determined in all the albino rats using urease Berthelot for urea, modified Jaffe's for creatinine while ion selective electrode analyzer was used for sodium, potassium and chloride. The data was subjected to statistical analysis using statistical package for social sciences (SPSS) version 20. The result showed that there was a significant increase $(P<0.05)$ in the mean value of serum urea $(\mathrm{mmol} / \mathrm{l})$, creatinine $(\mathrm{mg} / \mathrm{dl})$, sodium $(\mathrm{mmol} / \mathrm{l})$, potassium $(\mathrm{mmol} / \mathrm{l})$ and chloride $(\mathrm{mmol} / \mathrm{l})$ in trypanosome infected group $(29.00 \pm 0.6,4.00 \pm 0.35,154.52 \pm 2.67,20.74 \pm 13.59$ and $129.23 \pm 0.23)$ respectively when compared to control $(13.55 \pm 0.47,1.25 \pm 0.65 .133 .40 \pm 1.42,2.15 \pm 0.02$ and $101.18 \pm 1.43)$ respectively. The diamenazene treated showed a significant increase $(P<0.05)$ in the mean value urea $(\mathrm{mmol} / \mathrm{l})$, sodium $(\mathrm{mmol} / \mathrm{l})$, potassium $(\mathrm{mmo} / \mathrm{l})$, chloride $(\mathrm{mmol} / \mathrm{l})$ and significant decrease in creatinine $(\mathrm{md} / \mathrm{dl})(19.28 \pm 0.23$, $138.30 \pm 1.50,4.04 \pm 0.11,1.0292 \pm 0.93$ and $1.00 \pm 0.13)$ respectively when compared to control $(13.55 \pm 0.47,133.40 \pm 1.42,2.15 \pm 0.02,101.18 \pm 1.43$ and $1.25 \pm 0.65)$ respectively. The vitamin B12 treated group showed a significant increase $(P<0.05)$ in the mean value of serum urea $(\mathrm{mmol} / \mathrm{l})$, creatinine $(\mathrm{mg} / \mathrm{dl})$, sodium (mmol/l), potassium (mmol/l) and chloride (mmol/l) in all doses; 40mcg $(22.28 \pm 0.72,2.03 \pm 0.34$, $149.60 \pm 1.38,6.27 \pm 0.39$ and $116.48 \pm 4.74)$, $60 \mathrm{mcg}(21.45 \pm 0.83,2.10 \pm 0.14,153.40 \pm 2.58,5.77 \pm 0.26$ and $119.28 \pm 7.80)$ and $80 \mathrm{mcg}(21.28 \pm 0.38,2.50 \pm 0.27,152.40 \pm 0.99,6.22 \pm 0.39$ and 111.95 \pm 2.94$)$ respectively when compared to the control group $(13.55 \pm 0.47,1.25 \pm 0.65,133.40 \pm 1.42,2.15 \pm 0.02$ and $101.18 \pm 1.43)$ respectively. The result of the study suggested that oral administration of vitamins $B 12$ and E reduced the changes in renal dysfunction associated with Trypanosoma brucei brucei infection in Wistar albino rats.

Keywords: Vitamin B12, Renal function, Trypanosome.
\end{abstract}




\section{Introduction}

Human African trypanosomiasis (HAT or sleeping sickness) has been claimed to be more deadly than any other vector-borne disease such as malaria, because death is inevitable if a patient is not treated ${ }^{[1]}$. In spite of the existence of a huge body of research findings on African trypanosomosis (trypanosomiasis), the disease has continued to wreak havoc on human and animal lives with consequent effects on the fragile economy of countries of Tropical Africa ${ }^{[2,3]}$. Variable disorders occur sequel to trypanosome infection in animals. An in-depth knowledge of mechanisms of their development is pivotal to search for and identification of molecular targets, which could be exploited in evolution of therapeutic approaches, especially, in this cutting edge period of research in molecular medicine and biotechnology. Drug regimen are cumbersome in addition to being expensive $^{[4,5]}$. The search for new drugs and formulations that are safe and effective against both the early and late stages of the diseases is recommended ${ }^{[6,7,8]}$. Trypanosomiasis is a parasitic disease of people and animals, caused by protozoa of the Trypanosoma genus and transmitted by the tsetse fly ${ }^{[9]}$.

Vitamin B12 is a water-soluble vitamin that is naturally present in some foods, added to others, and available as a dietary supplement and a prescription medication ${ }^{[10,11]}$. Vitamin $\mathrm{B} 12$ is otherwise called cobalamins. The active forms of vitamin B12 in human metabolism are Methylcobalamin and 5-deoxyadenosylcobalamin is the forms of vitamin B12 that are active in human metabolism. Vitamin B12 functions in red blood cell formation, neurological function, and DNA synthesis ${ }^{[11]}$. Vitamin B12 also serves as a cofactor for Methionine synthase which catalyzes the conversion of homocysteine to methionine ${ }^{[12]}$. The aim of this study is to ascertain the effect of vitamin $\mathrm{B}_{12}$ on renal function of trypanosomeinfected male wistar albino rats using indicators such as urea, creatinine, sodium, potassium and chloride.

\section{Materials and Method}

\section{Study Animals}

A total of 24 male rats weighing between 100$180 \mathrm{~g}$ were obtained from animal house of the Department of Veterinary Medicine, Faculty of Veterinary Medicine, University of Nigeria Nsukka, Enugu State. They were housed and allowed to acclimatize for two weeks at the Pharmacy animal house of Madonna University, Elele, Rivers state. The animals were kept under normal room temperature and were fed with rat pellet and water ad libitum, the cages were cleaned daily to prevent infection of the animals.

\section{Reagents}

Commercially prepared Urea and creatinine reagents were obtained from Randox Diagnostics London.

\section{Vitamin B12}

Vitamin B12 (cyanocobalamine) was procured at Science Line, New Parts, Onitsha, Nigeria (molecular weight $1355.39 \mathrm{~g} / \mathrm{mol}$ and $96 \mathrm{ml}$ volume). The working concentration was determined at the Faculty of Pharmacognosy, Madonna University, Nigeria, Elele campus. The working volume of vitamin B12 was administered via intubation (orally) using distilled water as vehicle.

\section{Procurement of Trypanosome Parasite}

Trypanosoma brucei brucei infected male wistar albino rats were procured from Veterinary Department, Faculty of Veterinary Medicine, University of Nsukka, Enugu state.

\section{Inoculation of Rats with Trypanosomes}

Trypanosoma brucei brucei was obtained from an experimental infected rat previously inoculated with the parasite from Veterinary Parasitology of the University of Nigeria Nsuka. This was used to inoculate one rat and after 7 days of inoculation, the blood of that rat was used to inoculate others in each group. Each experimental rat was administered $0.1 \mathrm{ml}$ of infected blood in $0.3 \mathrm{ml}$ normal saline containing $1 \times 10^{6}$ trypanosomes using rapid matching method to determine the 
level of parasitaemia ${ }^{[13]}$. All rats except the controls were inoculated, marked and kept in their respective cages.

\section{Determination of Parasitaemia}

About one micro-litre of blood smear was placed on a clean grease-free glass slides, thin and thick smears were made with the aid of another microscope slide. The slide was air dried and fixed in methanol for three minutes. It was then stained in $10 \%$ Giesmsa, air dried and examined under the microscope using $\mathrm{x} 40$ and $\mathrm{x} 100$ objective. Identification of parasite was done using morphological description.

\section{Animal Experiment}

At the end of the acclimatization, animals were randomly selected into five groups of four rats each. Group A served as normal control and were given normal rat chow and water. Group B served as negative control and were infected with $1 \times 10^{6}$ trypanosome without treatment. Group $\mathrm{C}$ were infected with $1 \times 10^{6}$ trypanosome and treated with the standard drug (diamenazeacetuate). Group D (low dose of vitamin $\mathrm{B}_{12}$ ) was infected with $1 \times 10^{6}$ of trypanosome and was treated with $40 \mathrm{mcg} / \mathrm{kg}$ of vitamin $\mathrm{B}_{12}$; Group $\mathrm{E}$ (enriched dose of vitamin $B_{12}$ ) was infected with $1 \times 10^{6}$ of trypanosome and treated with $60 \mathrm{mcg} / \mathrm{kg}$ of vitamin $\mathrm{B}_{12}$; Group $\mathrm{F}$ (high dose of vitamin $\mathrm{B}_{12}$ ) was infected with $1 \times 10^{6}$ of trypanosome and treated with $80 \mathrm{mcg} / \mathrm{kg}$ of vitamin $\mathrm{B}_{12}$; The treatment lasted for 14 days. Blood samples were collected through the retrobulbar plexus of the medial canthus of the eye of the rats. A microcapillary tube was inserted into the canthus of the eye to puncture the retro-bulbar plexus and thus enable the out flow of about $2 \mathrm{ml}$ of blood into a clean test tube. The blood sample was kept at room temperature for 30minutes to clot. Afterwards, the test tube containing the clotted blood sample was centrifuged at 3,000 revolutions per minute for 10 minutes using a table centrifuge to enable a complete separation of the serum from the clotted blood. The clear serum supernatant was separated and stored in a clean sample bottle determinations.

\section{Biochemical analysis}

Electrolytes estimation (Sodium, Potassium and Chloride)

Method: Ion selective electrode analyser ${ }^{[14]}$. ISE principle/ theory: The analyser utilises Ion Selective Electrode (ISE) technology. ISE is a type of electrochemical sensor. It converts the ion activity to the electric potential of the electrode. The relation conforms to the NERST equation, that the logarithm of the ion activity has a linear relation with the electrode potential. In addition, different electrode are sensitive to different ions, for example sodium electrode is only sensitive to $\mathrm{Na}$ ions and potassium electrode is only sensitive to $\mathrm{K}$ ions and chloride electrode is only sensitive to $\mathrm{Cl}$ ions. If $\mathrm{K}$ electrode, $\mathrm{Na}$ electrode and $\mathrm{Cl}$ electrode are being combined together, the $\mathrm{K}$ ions, $\mathrm{Na}$ ions, and $\mathrm{Cl}$ ions in the sample can be measured at the same time. The key part of the electrode is the sensitive membrane from the one hand; it is in contact with the sample, responds to the change of the concentration of certain ions in the sample. On the other hand, it is in contact with the internal filling solution, and converts the ionic induction to the electronic conduction through a silver thread i.e. internal electrode. In addition, there is a reference electrode; there is also an internal electrode. Its potential remains constant when the concentration of the solution changes, so it provides a reference point to measure the potential differences.

The instrument measures the electrode potentials, and the data is processed by the microprocessor, to obtain the concentration of a given ion. The measure method is called "standard comparison". It uses two kinds of standard solutions, one for cablibration of the basic point, other for the calibration of the slope. The result is obtained from the potentials of the sample and two standard solutions. Following are the equation;

$\mathrm{C}_{\mathrm{X}}=\mathrm{C}_{\mathrm{A}} * \mathrm{EXP}\left[\left(\mathrm{CE}_{\mathrm{X}}-\mathrm{E}_{\mathrm{A}}\right) / \mathrm{S}\right](1)$

$$
\mathrm{E}_{\mathrm{B}}-\mathrm{EA}
$$


$\mathrm{S}=$

$\log (\mathrm{CB} / \mathrm{CA})$

Note:

$\mathrm{C}_{\mathrm{X}}, \mathrm{EX}$; The concentration and potential of the sample

$\mathrm{C}_{\mathrm{A}}, \mathrm{EA}$; The concentration and potential of the sample A

$\mathrm{C}_{\mathrm{B}}$, EB; The concentration and potential of the sample B

$\mathrm{S}$; The slope of electrode

In order to improve the precision, the contents of the standard solutions should be similar with blood samples as much as possible.

Urea estimation was done by Urease - Berthelot colorimetric method. Ten (10) microlitre of sample, standard, control and distilled water was pipette into test tube labeled sample, standard control and blank respectively. Hundred (100) microlitre of urea reagent 1 was added to all the tubes and incubated at $37^{\circ} \mathrm{C}$ for 10 minutes. 250 microlitres of urea solutions 2 and 3 was added to all the tubes, mixed and incubated at $37^{\circ} \mathrm{C}$ for 15 minutes. The absorbance of the sample, control and standard were read at $546 \mathrm{~nm}$ against the content of the blank tube. The activity of sample was calculated using the absorbance of sample against absorbance of standard multiplied by concentration of standard $^{[15]}$.

Creatinine estimation was done by Jaffe's colorimetric method. Five hundred (500) millilitre of sample, standard, control and distilled water was pipette into test tube labeled sample, standard control and blank respectively containing five hundred (500) millilitre of trichloroacetic acid (TCA). The contents were mixed and spun at 2500rpm for 10minutes. 1000 millilitre of supernatant from each tube was added into respectively labeled test tube containing 1000 millilitre of reagent mixture of Picric acid and sodium hydroxide (500 millilitre each).The contents were mixed and stand at $25^{\circ} \mathrm{C}$ for 20 minutes. The absorbance of the sample, control and standard were read at $546 \mathrm{~nm}$ against the content of the blank tube. The concentration of sample was calculated using the absorbance of sample against absorbance of standard multiplied by concentration of standard ${ }^{[16]}$.

\section{Statistical Analysis}

The data was analyzed using statistical package for social sciences (SPSS) version 20 for windows and results were expressed as mean \pm standard error of mean (mean \pm SEM) while analysis of variance (ANOVA) was used to determine the difference between treatments. Statistical significance as obtained at $p<0.05$.

\section{Result}

Table1 below, showed that there was a significant increase $(\mathrm{P}<0.05)$ in the mean value of serum urea $(\mathrm{mmol} / \mathrm{l})$, creatinine $(\mathrm{mg} / \mathrm{dl})$, sodium $(\mathrm{mmol} / \mathrm{l})$, potassium $(\mathrm{mmol} / \mathrm{l})$ and chloride $(\mathrm{mmol} / \mathrm{l})$ in trypanosome infected group $(29.00 \pm 0.6$, $4.00 \pm 0.35, \quad 154.52 \pm 2.67, \quad 20.74 \pm 13.59$ and $129.23 \pm 0.23)$ respectively when compared to control (13.55 $\pm 0.47, \quad 1.25 \pm 0.65$. 133.40 \pm 1.42 , $2.15 \pm 0.02$ and $101.18 \pm 1.43$ ) respectively. The diamenazene treated showed a significant increase $(\mathrm{P}<0.05)$ in the mean value urea $(\mathrm{mmol} / \mathrm{l})$, sodium $(\mathrm{mmol} / \mathrm{l})$, potassium $(\mathrm{mmo} / \mathrm{l})$, chloride $(\mathrm{mmol} / \mathrm{l})$ and significant decrease in creatinine $(\mathrm{md} / \mathrm{dl})$ $(19.28 \pm 0.23, \quad 138.30 \pm 1.50, \quad 4.04 \pm 0.11$, $1.0292 \pm 0.93$ and $1.00 \pm 0.13)$ respectively when compared to control $(13.55 \pm 0.47,133.40 \pm 1.42$, $2.15 \pm 0.02, \quad 101.18 \pm 1.43$ and $1.25 \pm 0.65$ ) respectively. The vitamin B12 treated group showed a significant increase $(\mathrm{P}<0.05)$ in the mean value of serum urea $(\mathrm{mmol} / \mathrm{l})$, creatinine $(\mathrm{mg} / \mathrm{dl})$, sodium $(\mathrm{mmol} / \mathrm{l})$, potassium $(\mathrm{mmol} / \mathrm{l})$ and chloride $(\mathrm{mmol} / \mathrm{l})$ in all doses; $40 \mathrm{mcg}$ $(22.28 \pm 0.72,2.03 \pm 0.34,149.60 \pm 1.38,6.27 \pm 0.39$ and $116.48 \pm 4.74), 60 \mathrm{mcg}(21.45 \pm 0.83,2.10 \pm 0.14$, $153.40 \pm 2.58,5.77 \pm 0.26$ and $119.28 \pm 7.80)$ and $80 \mathrm{mcg} \quad(21.28 \pm 0.38, \quad 2.50 \pm 0.27, \quad 152.40 \pm 0.99$, $6.22 \pm 0.39$ and $111.95 \pm 2.94)$ respectively when compared to the control group (13.55 \pm 0.47 , $1.25 \pm 0.65, \quad 133.40 \pm 1.42, \quad 2.15 \pm 0.02$ and $101.18 \pm 1.43$ ) respectively. 
Table 1: Effect of graded dose of Vitamin B12 on renal function of albino rats infected with Trypanosoma brucei

\begin{tabular}{lccccc}
\hline Treatment & Urea $(\mathbf{m m o l} / \mathbf{l})$ & $\begin{array}{c}\text { Creatinine } \\
(\mathbf{m g} / \mathbf{d l})\end{array}$ & $\begin{array}{c}\text { Sodium } \\
(\mathbf{m m o l} / \mathbf{l})\end{array}$ & $\begin{array}{c}\text { potassium } \\
(\mathbf{m m o l} / \mathbf{l})\end{array}$ & $\begin{array}{c}\text { Chloride } \\
(\mathbf{m m o l} / \mathbf{l})\end{array}$ \\
\hline Control & $13.55 \pm 0.47$ & $1.25 \pm 0.65$ & $133.40 \pm 1.42$ & $2.15 \pm 0.02$ & $101.18 \pm 1.43$ \\
Trypanosome & $29.00 \pm 0.65$ & $4.13 \pm 0.34$ & $154.52 \pm 1.50$ & $20.74 \pm 13.59$ & $129.23 \pm 0.99$ \\
Diaminiazeneaceturate & $19.28 \pm 0.23$ & $1.00 \pm 0.13$ & $138.30 \pm 2.66$ & $4.04 \pm 0.11$ & $102,29 \pm 0.93$ \\
40mcg of vitamin B12 & $22.28 \pm 0.72$ & $2.03 \pm 0.34$ & $149.60 \pm 1.38$ & $6.27 \pm 0.39$ & $116.48 \pm 4.74$ \\
60mcg of vitamin B12 & $21.45 \pm 0.83$ & $2.10 \pm 0.14$ & $153.40 \pm 2.58$ & $5.77 \pm 0.26$ & $119.28 \pm 7.80$ \\
80mcg of vitamin B12 & $21.28 \pm 0.38$ & $2.50 \pm 0.27$ & $152.40 \pm 0.99$ & $6.22 \pm 0.39$ & $111.95 \pm 2.94$ \\
F & 12.141 & 7.304 & 11.116 & 1.396 & 2.598 \\
P & 0.000 & 0.000 & 0.000 & 0.000 & 0.004 \\
\hline
\end{tabular}

Table 2 below, showed that there was a significant increase $(\mathrm{P}<0.05)$ in the mean value of serum urea $(\mathrm{mmol} / \mathrm{l})$, creatinine $(\mathrm{mg} / \mathrm{dl})$, sodium $(\mathrm{mmol} / \mathrm{l})$, potassium $(\mathrm{mmol} / \mathrm{l})$ and chloride $(\mathrm{mmol} / \mathrm{l})$ in trypanosome infected group $(29.00 \pm 0.65, \quad 4.00 \pm 0.35, \quad 154.52 \pm 2.67$, $20.74 \pm 13.59$ and $129.23 \pm 0.99)$ respectively when compared to control $(13.55 \pm 0.47,1.25 \pm 0.65$, $133,40 \pm 1.42, \quad 2.15 \pm 0.02$ and $101.18 \pm 1.43)$ respectively. The diamenazene treated showed a significant increase $(\mathrm{P}<0.05)$ in the mean value urea, sodium, potassium, chloride and significant decrease in creatinine $(19.28 \pm 0.23,138.30 \pm 1.50$,
$4.04 \pm 0.11, \quad 102.29 \pm 0.93$ and $1.00 \pm 0.13 \mathrm{mg} / \mathrm{dl})$ respectively when compared to control $(13.55 \pm 0.47,133.40 \pm 1.422 .15 \pm 0.02,101.18 \pm 1.43$ and $1.25 \pm 0.65)$ respectively. The vitamin B12 treated group showed a significant increase $(\mathrm{P}<0.05)$ in the mean value of serum urea, creatinine, sodium, potassium and chloride $(21.67 \pm 0.37,2.21 \pm 0.15,1.52 \pm 1.10,6.09 \pm 0.19$ and $1.16 \pm 3.03)$ respectively when compared to the control group $(13.55 \pm 0.47, \quad 1.25 \pm 0.65$, $133.40 \pm 1.42,2.15 \pm 0.02$ and $101.18 \pm 1.43 \mathrm{mmol} / \mathrm{l})$ respectively.

Table 2: Effect of Vitamin B12 on renal function of albino rats infected with Trypanosoma brucei

\begin{tabular}{lccccc}
\hline Treatment & $\begin{array}{c}\text { Urea } \\
(\mathbf{m m o l} / \mathbf{l})\end{array}$ & $\begin{array}{c}\text { Creatinine } \\
(\mathbf{m g} / \mathbf{d l})\end{array}$ & $\begin{array}{c}\text { Sodium } \\
(\mathbf{m m o l} / \mathbf{l})\end{array}$ & $\begin{array}{c}\text { Potassium } \\
(\mathbf{m m o l} /)\end{array}$ & $\begin{array}{c}\text { Chloride } \\
(\mathbf{m m o l})\end{array}$ \\
\hline Control & $13.55 \pm 0.47$ & $1.25 \pm 0.65$ & $133.40 \pm 1.42$ & $2.15 \pm 0.02$ & $101 \pm 1.43$ \\
Trypanosome & $29.00 \pm 0.65$ & $4.00 \pm 0.35$ & $154.52 \pm 2.67$ & $20.74 \pm 13.59$ & $132.23 \pm 0.93$ \\
Diamenazine & $19.28 \pm 0.23$ & $1.00 \pm 0.13$ & $138.30 \pm 1.50$ & $4.04 \pm 0.11$ & $102.29 \pm 0.99$ \\
Vitamin B 12 & $21.67 \pm 0.37$ & $2.21 \pm 0.15$ & $152.17 \pm 1.10$ & $6.09 \pm 0.19$ & $115.90 \pm 3.03$ \\
F & 32.530 & 16.210 & 26.600 & 5.670 & 7.220 \\
P & 0.000 & 0.000 & 0.000 & 0.000 & 0.000 \\
\hline
\end{tabular}

\section{Discussion}

It was observed that infection with Trypanosoma brucei brucei, caused increase in serum levels of urea, Creatinine, sodium, potassium and chloride. This agrees with the findings of Ismaila et al. ${ }^{[17]}$ and Umar et al. ${ }^{[18]}$ who reported increase in serum levels of renal markers in trypanosomiasis. Increases in the levels of these paremeters are indications of damage to the kidney ${ }^{[19]}$ and several workers have reported generalized degenerative changes in kidney and other organs in trypanosomiasis $^{[20,21]}$. The alterations observed in the serum concentrations of the urea, creatinine, sodium, potassium and chloride could involve many pathophysiological mechanisms ${ }^{[22]}$.

After treatment of Trypanosoma brucei brucei with Vitamin B12 the result showed a significant decrease $(\mathrm{P}<0.05)$ in the concentration of serum urea, creatinine, sodium, potassium and chloride when compared to the untreated group. The decrease in the concentration of serum urea, creatinine, sodium, potassium and chloride seen in this study contrasted the work of Vanveilthuysen et $a l^{[23]}$ who reported an increased renal markers concentration in humans infected with Trypanosoma bruceigam biense. Decreased serum 
urea, creatinine, sodium, potassium and chloride in the animals infected and treated with vitamin B12, as evident in this study is similar to observations found in other mammalian hosts parasitized by trypanosome species and treated with a trypanocidal; diminazene aceturate ${ }^{[24]}$. The result obtained in this present study also agrees with the works of Herbert and Das ${ }^{[10]}$ who reported on the Anti-parasitic effect of vitamin B12 on Trypanosoma cruzi.

\section{Conclusion}

The study has shown that Vitamin B12 reversed the increases ofurea, Creatinine, sodium, potassium and chloride caused by Trypanosoma brucei brucei.

\section{References}

1. Kennedy, P.G.E. (2004). Human African Trypanosomiasis of the CNS: Current issues and challenges. Journal of Clinical investigation, 113,496-504

2. Kristjanson P.M., Swallow B.M., Rowland G.J., Krusoka R.L.,Belew P.P.(1999).Measuring the cost of animal African trypanosomiasis, the potential benefit of control and returns to research. Agr.Sys. 59(1) 79-98.

3. Bourn D., Grant I, Shaw A., Torr S, (2005). Cheap and safe tsetse control for livestock production and mixed farming in Africa. Asp. Appl. Biol. 75

4. Kioy D. and Mattock, N. (2005). Control of sleeping sickness time to integrate approaches. Lancet 366(9487)695-696

5. Moore, AC (2005). Prospects for improving African trypanosomiasischemotheraphy. J. infectious Dis. 191 1793-1795

6. Jannin J. and Cattand, P (2004). Treatment and control of human African trypanosomiasis. Current Opinion Infection Disease 17; 565-571

7. Chibale K. (2005). Economic drug discovery and rational medicinal chemistry for tropical diseases. Pure Applied Chem. 77 1957-1964

8. Pink R., Hudson A., Mouries M-A., Bendig M. (2005).Opportunities and anti parasitic drug discovery. National Review Drug Discover 49:727-740,

9. WHO (World Health Organization) (2006). African trypanosomiasis (sleeping sickness)

http://www.who.int/mediacentre/factsheet/ fs 259/ena.

10. Herbert V, Das K.(1994) Vitamin B12 in Modern Nutrition in Health and Disease. 8th ed. Baltimore, MD: Williams \& Wilkins, 63:12-24

11. Combs G.( 1992) .Vitamin B12 in The Vitamins. New York: Academic Press, Inc.,

12. Clarke R. B. (2008). Vitamins and prevention of dementia. Proc Nutrition Society, 67:75-81.

13. Herbert W. J, and Lumsden W. H (1976) Trypanosoma brucei: a rapid "matching" method for estimating the hostsparasitemia. Exp. Parasitology,40 (3):427-31.

14. Ion selective electrode series operator manual (2012). SFRI, Medical Diagnostics, 18-19.

15. Weatherburn, M.W. (1967). Phenolhypochlorite reaction for determination of ammonia. Analytical Chemistry, 39:971974.

16. Henry R.J.(1974). Creatinine in: Clinical Chemistry, principles and techniques.2nd edition, Harper and Row4:510-525.

17. Ismaila AU, Zipporah AT, Funnilayo II, Abubakar G. Lawan BB (2000). The Role of Vitamin B12 and E Administration in Alleviation of kidney Damage in Rats Infected with Trypanosoma brucei. Journal of Clinical Biochemical. Nutrition.28: 1-7.

18. Umar I.A, Rumah B.L, Asueliman B.I, Mazai M.H, Ibrahim M.A, Isah S. (2008): Effects of intraperitoneal administration of 
vitamins $\mathrm{B} 12$ and $\mathrm{E}$ combinations on the severity of Trypanosoma brucei brucei infection in rats. African Journal of Biochemical Research,2 (3): 088-091.

19. Kaplan L.A, Szabo L.L, Opherin E.K. (1988). Renal markers in clinical chemistry: Interpretation and Techniques. 3rd eds. Lea and Febliger, Philadelphia.9:182 - 184.

20. Anosa V.O, Kaneko J.J. (1984). Pathogenesis of $\mathrm{T}$ bruceiinfection in deer mice (P. maniculatus). Ultra structural pathology of the spleen, liver, heart and kidney. Veterinare Pathology,21:229-237

21. Bruijn J.A, Oemar B.S, Ehrick H.H, Foidart J.M., Flueures G.J. (1987). Antibasement membrane glomerulopathy in experimental trypanosomiasis. Journal of Immunology. 139:2482- 2485.

22. Adamu, U. O., Orbagbedia R. P., Nwezor F.N.C. and Muhammed M. (2008). T. brucei infection of rabbits. Journal of Parasitology, 3:1-5

23. Vanveilthuysen M.L., Bruijn J.A. and Vanleer E.H. (1992). Pathogenesis of trypanoaomiasis induced glomerulonephritis in mice. Nephrol Dial Transplant, 7:507-51

24. Kahn C. M. (2005). Blood parasites. The Merck Veterinary Manual, Merck \& Co. inc. 